\title{
Assessing airborne PM-bound arsenic exposure risk in semiconductor manufacturing facilities
}

\author{
Wei-Chun Chou, Chia-Pin Chio, Chung-Min Liao* \\ Department of Bioenvironmental Systems Engineering, National Taiwan University, Taipei 10617, Taiwan, ROC
}

\section{A R T I C L E I N F O}

\section{Article history:}

Received 24 November 2008

Received in revised form 21 January 2009

Accepted 21 January 2009

Available online 30 January 2009

\section{Keywords:}

Airborne arsenic

Particular matter

Oxidative stress

Respiratory tract

PBPK model

Risk assessment

Semiconductor

\begin{abstract}
A B S T R A C T
The purpose of this study was to investigate the inhalation risks on the workers (operator and administrator) exposure to airborne particulate matter-bound arsenic (PMAs) in semiconductor manufacturing facilities. We reanalyzed published empirical data of the personal exposure levels and size distributions of airborne PMAs and linked a human respiratory tract model to calculate the concentrations deposited in target lung regions. We used a physiologically based pharmacokinetic model with a dose-response relationship based on an empirical three-parameter Hill equation model to simulate the exposure time-dependent arsenic dose profiles in human tissues and to estimate quantitatively the inhalation exposure risks. Results show that the threshold level of As(III) for lipid peroxidation response (LPO) on human lung epithelial cells was estimated to be 11.89 (95\% CI: 8.09-15.69) $\mu \mathrm{M}$, whereas 16.39 (95\% CI: 12.56-20.22) $\mu \mathrm{M}$ for oxidative DNA damage on human dermal cells. Risk analysis shows that the LPO responses were estimated to be 3.79 (95\% CI: 2.44-5.33) for operator and 0.03 (95\% CI: $0.01-0.10$ ) for administrator at a risk of 0.5 . The $10 \%$ probability (risk $=0.1$ ) of human dermal cells affected by oxidative DNA damage responses is approximately $27.21 \%$ (95\% CI: $12.71-67.02 \%)$ for operator and $0.03 \%$ (95\% CI: $0.01-0.07 \%$ ) for administrator. This study suggests that a potential link between inhalation exposure risk of operator to airborne PMAs in semiconductor manufacturing workplace.
\end{abstract}

(c) 2009 Elsevier B.V. All rights reserved.

\section{Introduction}

Manufacturing process in the semiconductor facilities involves exposure of workers to many hazardous chemicals embracing arsenic, solvents, photoactive polymers and other materials. Among them, potential occupational arsenic exposure is one of the most significant problems. Inorganic arsenic and its compound have widely used in semiconductor manufacturing processes including metal organic chemical vapor deposition, ion implantation and diffusion, etc. [1,2]. During processing, arsenic-containing byproducts, such as arsenic trioxide, could possibly deposited on the inside reaction chamber surfaces. These by-products can generate the particulate matter-bound arsenic (PMAs), which may therefore pose a potential arsenic exposure risk to workers through the inhalation or dermal contact while performing their tasks [3-5].

Toxicity of arsenic involves many organ systems including gastrointestinal, dermal, nervous, renal, hepatic, hematopoietic, cardiovascular, respiratory and ophthalmic systems [6]. Long-term exposure to inorganic arsenic has been associated with skin lesions, peripheral vascular disease, hyperkeratosis, chronic lung disease and significant high risk of cancers [7-9]. On the other hand, several

\footnotetext{
* Corresponding author. Tel.: +88622363 4512; fax: +886223626433.

E-mail addresses: cmliao@ntu.edu.tw, cmliao@ccms.ntu.edu.tw (C.-M. Liao).
}

in vivo and in vitro studies have found that PMAs are degraded under physiologically relevant in vitro conditions to release inorganic arsenic, which are then distributed to major target organs [10-11]. The result supports the concept that the systemic involvement of arsenic toxicity may result from the generalized distribution of ingested and inhaled PMAs in human body. The published epidemiological studies, however, cannot reflect the arsenic distributed to major target organs via ingestion or inhalation of PMAs on human adverse health risk, suggesting that quantification of arsenic released by airborne PMAs is worth to be considered to assess the internal dose for human exposure.

Many researchers have found that inorganic arsenic can cause the mutagenic and genotoxic effects to exposure of experimental animals and cultured human cells through the generation of oxidative stress (OS) [12-14]. The OS is thought to be an important mechanism of damage for inorganic arsenic, which is caused through the production of reactive oxygen species (ROS) including peroxides and free radicals that damage all components of the cells (protein, lipids, DNA and RNA) [15,16].

Arsenite $(\mathrm{As}(\mathrm{III}))$ has been shown to enhance the production of lipid peroxidation (8-isoprostane), an indicator of OS and to increase the accumulation of oxidative DNA lesions (e.g. $80 \mathrm{HdG}$ ) in in vitro studies $[17,18]$. Acute and chronic intake of arsenic increased lipid peroxides in blood, liver, kidney, and other organs of rats $[19,20]$. Elevated serum and urinary levels of lipid 


\begin{tabular}{|c|c|}
\hline \multicolumn{2}{|c|}{ Nomenclature } \\
\hline$K_{\mathrm{abs}}$ & absorption rate constant $\left(\mu \mathrm{mol} \mathrm{h}^{-1}\right)$ \\
\hline $\mathrm{As}(\mathrm{III})$ & arsenite \\
\hline $\mathrm{As}(\mathrm{V})$ & arsenate \\
\hline$W_{\text {Biliary }}$ & bile elimination amount \\
\hline$F_{i}$ & blood flow fraction (\%) \\
\hline$Q_{j}$ & blood flow in tissue $j\left(\mathrm{Lh}^{-1}\right)$ \\
\hline BW & body weight (kg) \\
\hline$A B$ & breathing rate $\left(\mathrm{m}^{3} \mathrm{~h}^{-1}\right)$ \\
\hline$Q_{\mathrm{f}}$ & breathing frequency (breath $\min ^{-1}$ ) \\
\hline$Q_{T}$ & cardiac output rate $\left(\mathrm{L} \mathrm{min}^{-1}\right)$ \\
\hline$C_{j}^{i}$ & $\begin{array}{l}\text { concentration of arsenic species } i \text { in tissue } j \\
\left(\mu \mathrm{mol} \mathrm{L}^{-1}\right)\end{array}$ \\
\hline$D_{i}$ & density of tissue $i\left(\mathrm{~kg} \mathrm{~L}^{-1}\right)$ \\
\hline$d_{k}$ & diameter of airways $(\mathrm{cm})$ \\
\hline DMA & dimethylarsenic acid \\
\hline$A_{j}^{i}$ & dose of arsenic species $i$ in tissue $j(\mu \mathrm{mol})$ \\
\hline TS & duration of working $\left(\mathrm{h} \mathrm{d}^{-1}\right)$ \\
\hline$K_{\text {eli }}$ & elimination constant $\left(\mu \mathrm{mol} \mathrm{h}^{-1}\right)$ \\
\hline GI & gastrointestinal \\
\hline$W_{\text {day }}$ & human daily drinking water amount $\left(\mathrm{Lh}^{-1}\right)$ \\
\hline HRT & human respiratory tract \\
\hline$C_{I}$ & input PMAs concentrations $\left(\mu \mathrm{g} \mathrm{m}^{-3}\right)$ \\
\hline LPO & lipid peroxidation \\
\hline$V_{\max , j}^{i \rightarrow k}$ & $\begin{array}{l}\text { maximum reaction rate for arsenic } i \text { methylated to } \\
k \text { in tissue } j\end{array}$ \\
\hline MMA & methylarsenic acid \\
\hline$K_{m, j}^{i}$ & $\begin{array}{l}\text { Michaelis-Menten constant for arsenic species } i \text { in } \\
\text { tissue } j\left(\mu \mathrm{mol} \mathrm{L}^{-1}\right)\end{array}$ \\
\hline MC & Monte Carlo \\
\hline NP & nasopharynx \\
\hline$n_{j}$ & number of airways \\
\hline OS & oxidative stress \\
\hline$d_{\mathrm{p}}$ & particle diameter $(\mu \mathrm{m})$ \\
\hline PMAs & particulate matter-bound arsenic \\
\hline$W_{j}$ & percentage of the mass of organ $j$ in the body weight \\
\hline PBPK & physiologically based pharmacokinetic \\
\hline $\mathrm{P}$ & pulmonary \\
\hline ROS & reactive oxygen species \\
\hline$C_{k}$ & $\begin{array}{l}\text { state variable concentration of PMAs in lung regions } \\
k(\mu \mathrm{g})\end{array}$ \\
\hline$V_{\mathrm{t}}$ & tidal volume $(\mathrm{L})$ \\
\hline$P_{j}^{i}$ & $\begin{array}{l}\text { tissue/blood partition coefficient of arsenic } i \text { in } j \text { tis- } \\
\text { sue }\end{array}$ \\
\hline ТВ & tracheobronchial \\
\hline$\beta$ & transition coefficient \\
\hline$K_{\text {uptake }}$ & uptake constant for arsenic $\left(\mu \mathrm{mol} \mathrm{h}^{-1}\right)$ \\
\hline & volume of tissue $j(\mathrm{~L})$ \\
\hline \multicolumn{2}{|c|}{ Subscript } \\
\hline$i$ & arsenic species ( $\mathrm{As}(\mathrm{III}), \mathrm{As}(\mathrm{V}), \mathrm{MMA}$ and $\mathrm{DMA})$ \\
\hline$j$ & tissue group (lung, kidney, skin, GI tract and liver) \\
\hline$k$ & $\begin{array}{l}\text { lung regions (nasopharynx, tracheobronchial and } \\
\text { pulmonary) }\end{array}$ \\
\hline
\end{tabular}

peroxides and oxidative DNA lesions have been detected in several epidemiological studies [21-23]. Furthermore, some investigations have provided evidence that arsenic and its metabolites are capable of altering biologically several cellular defense mechanisms involved in the carcinogenic process through activation of oxidative-sensitive signaling pathways $[24,25]$.
Evidence indicated that in the absence of proper controls the potential arsenic exposure of workers was estimated to be significantly higher than the $0.01 \mathrm{mg} \mathrm{m}^{-3}$ exposure limit during cleaning and maintenance operations for solid-source ion implanters [26]. In Taiwan, operators at a semiconductor manufacturing facility were exposed to higher levels of PMAs ranging from 5.26 to $106.12 \mu \mathrm{g} \mathrm{m}^{-3}$ [5]. Hwang et al. [4] also pointed out that the concentration of total urinary arsenic metabolites showed significant increasing trend for ion implanter maintenance engineers. Despite much evidence indicated that higher levels of occupation arsenic exposure for semiconductor workers, little is known about PMAs in semiconductor manufacturing facility by which a potential health risk to workers working in the facility may pose.

The objectives of this study are twofold: (1) to quantify the cumulative dose profiles of arsenic in human internal tissues and (2) to employ the probabilistic risk approach to estimate the OS risk on human exposure to airborne PMAs for workers working at semiconductor manufacturing facility. We reanalyzed published data of PMAs measured in semiconductor manufacturing facility and incorporated human respiratory tract (HRT) model to estimate the PMAs mass concentration in lung regions. A physiologically based pharmacokinetic (PBPK) model was used to further describe the cumulative dose of arsenic in specific organs. We combined predicted cumulative dose of arsenic in lung and skin tissues and dose-response relationships derived from published experimental studies on human lung and skin cells allowing us to assess OS risk. To evaluate overall uncertainty in the risk estimates, the uncertainties resulting from the assessment of exposure and dose-response are propagated through the risk characterization using Monte Carlo (MC) analysis.

\section{Materials and methods}

Our probabilistic risk assessment framework is divided into four parts (Fig. 1) and will be described in the subsequent sections.

\subsection{Problem formulation: data reanalysis}

Little empirical data existed regarding airborne PMAs information in semiconductor manufacturing facilities. Therefore, we must rely on data reanalysis technique linking with whatever empirical data is available. Airborne PMAs concentrations and particle size distribution in semiconductor manufacturing facilities were obtained from published literature where available. Our study was focused on two selected worker groups in semiconductor manufacturing facility, including operator and administrator. The major database of workers exposed to airborne PMAs is adopted from Chen [5]. Briefly, a total 144 workers including 72 production workers known as operators and 72 office administrators known as reference group were selected. Both sample collection and biological monitoring were carried out for all selected workers. The information of particle size distributions of airborne PMAs was reanalyzed and optimal fitted to the published data adopted from Álvarez et al. [27] and Herner et al. [28]. PMAs distributions of semiconductor manufacturing facility also determined following the fitted size distributions along with the reported concentration data. The Kolmogorov-Smirnov (K-S) statistics was used to optimize the goodness-of-fit of the distribution of observed data by performing the Statistica ${ }^{\circledR}$ software package (StatSoft, Tulsa, OK, USA).

\subsection{Exposure analysis}

We present an approach by linking HRT and PBPK models to quantitatively estimate the relationship between exposure to PMAs 


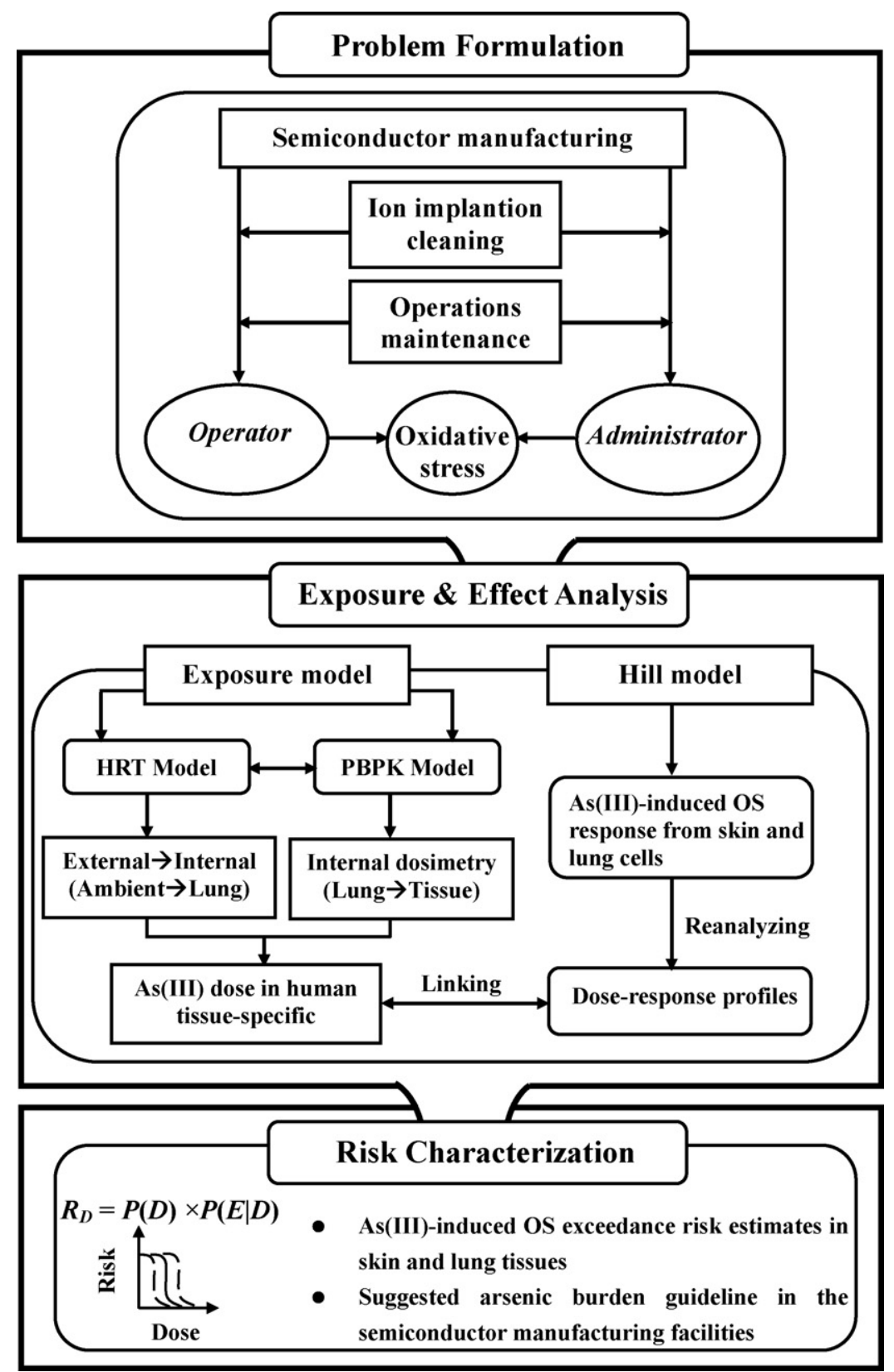

Fig. 1. Proposed probabilistic risk assessment framework to assess oxidative stress risk for semiconductor workers exposed to PMAs.

and tissue dosimetry while taking explicitly account of the physiological characteristics of the biological system in the species under investigation. These models consist of three absorption compartments, six target tissues compartments and four excretion compartments (Fig. 2).

\subsubsection{HRT model}

We used a HRT model developed by ICRP [29] to estimate the exposure concentrations from ambient PMAs into various lung regions. The HRT model is capable of describing the progress over time of the penetration, deposition, and clearance of particles in the pulmonary region depended on breathing frequency, tidal volume, particle size distribution, and concentration of the particles [29].

Lung was mainly divided into three regions when applying HRT model (Fig. 2A): (i) the nasopharynx (NP), comprising the anterior nose, posterior nasal passages, larynx and mouth; (ii) the tracheobronchial (TB), comprising the airway from the trachea, main bronchi, intrapulmonary bronchi and terminal bronchioles; and (iii) the pulmonary $(\mathrm{P})$, comprising the airway from respiratory bronchioli through alveolar sacs. Liao and Chen [30] and Chio et al. [31] have comprehensively described the HRT model framework and the essential model parameters that characterizing the model structure and function. Based on the principle of mass balance, the HRT model varying with particle size range and time to each regional compartment are given by linear dynamic equations (Appendix $A$ for Eqs. (A.1)-(A.3)) with new parameter groupings to describe the dynamic behavior of HRT model (Table 1 ).

On the other hand, the PMAs deposited in all three compartment regions can be absorbed into the plasma based on the lung clearance mechanisms (ICRP [29]). The absorbed process of PMAs from these compartments into the plasma is described using first-order kinetic 


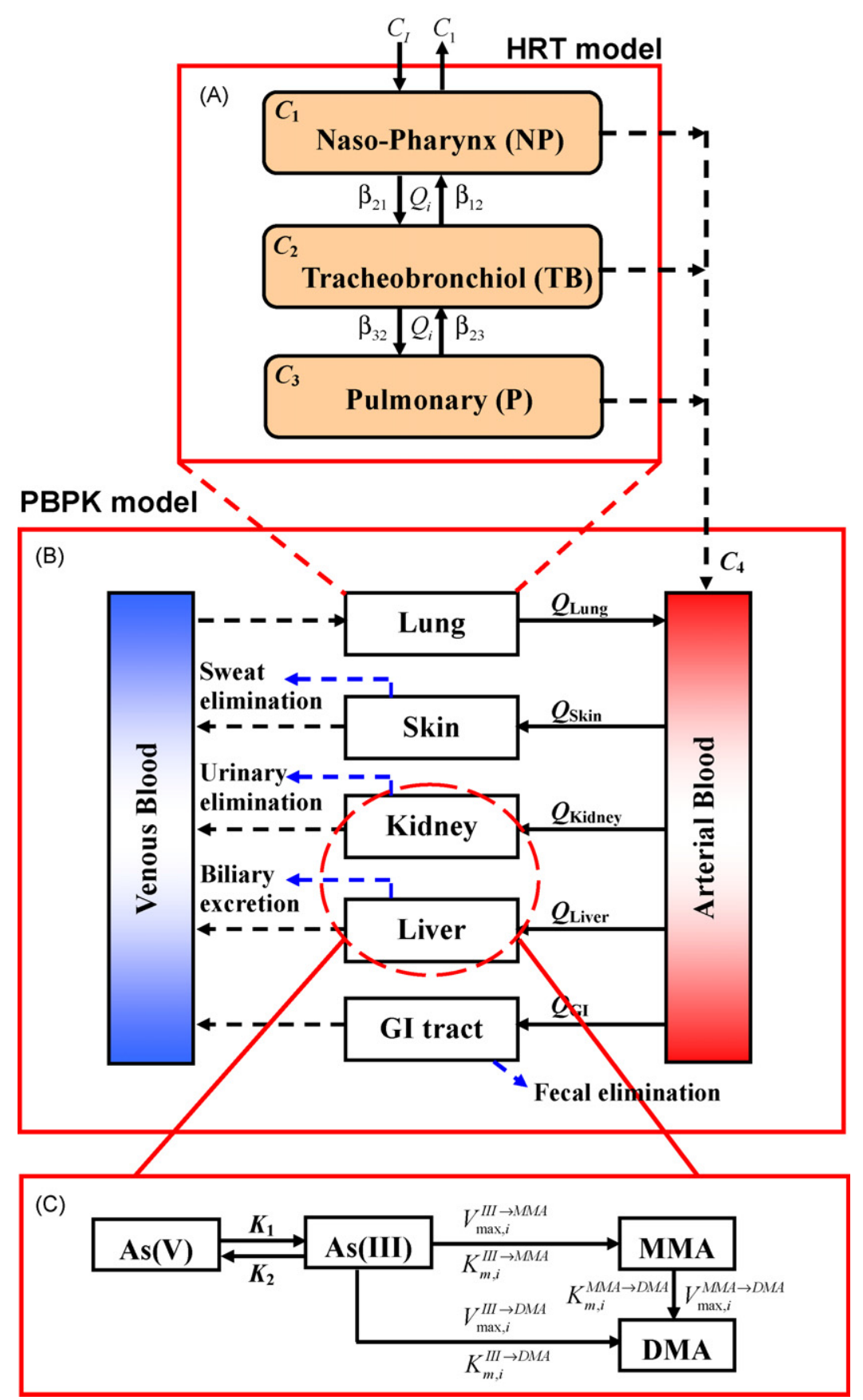

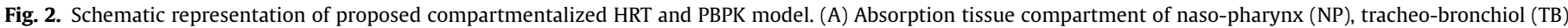

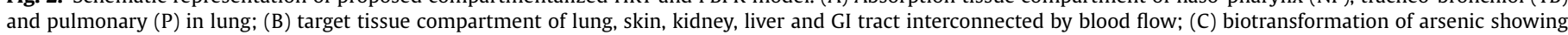
oxidation/reduction of inorganic arsenic and methylation of $\mathrm{As}(\mathrm{III})$ in kidney and liver.

equation (Appendix A for Eq. (A.4)). Here we reasonably assumed that PMAs deposited in these compartments could be in the form of $\mathrm{As}(\mathrm{III})$ absorbed by plasma.

\subsubsection{PBPK model}

For simulating the distribution of arsenic dosimetry in the human tissues, we appropriately refined the basic compartmental structure that has been previously employed in many PBPK models for arsenic exposure in humans to describe the pharmacokinetics and metabolism of arsenic in target tissues [32-34]. The major tissue compartments (Fig. 2B) include in the model consisting of lung, liver, kidney, GI tract and skin. Each tissue compartment was interconnected by blood flow (blood constitutes one compartment with venous and arterial blood). The biotransformation of arsenic in the body consists of an oxidation/reduction and two methylation reactions. The oxidation/reduction of inorganic arsenic takes place in the plasma and in the kidney and liver, whereas the methylation of $\mathrm{As}(\mathrm{III})$ takes place mainly in the liver and kidney according to Michaelis-Menten kinetics (Fig. 2C) [35].

The dynamic behavior and metabolic processes in the PBPK model can be described by a set of first-order differential equations (see Appendix A for detail). The physiological parameters, metabolic constants, tissue/blood partition coefficient and biochemical parameters are listed in Tables 1 and 2. We employed the MATLAB $^{\circledR}$ software (The Mathworks Inc., MA, USA) to perform the PBPK simulations. 
Table 1

Input physiological parameters used in the HRT and PBPK model.

\begin{tabular}{|c|c|c|}
\hline Parameter & Description & Values \\
\hline \multicolumn{3}{|c|}{ Lung physiological parameters ${ }^{\mathrm{a}}$} \\
\hline$Q_{i}$ & 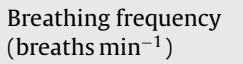 & $15-20$ \\
\hline $\mathrm{AB}$ & $\begin{array}{l}\text { Respiratory rate } \\
\left(\mathrm{m}^{3} \mathrm{~h}^{-1}\right)\end{array}$ & $2.1-1.4$ \\
\hline$V_{\mathrm{t}}$ & Tidal volume (L) & $1.33,3$ \\
\hline$\lambda_{\mathrm{L}}$ & $\begin{array}{l}\text { Clearance rate by } \\
\text { phagocyte }\left(\mathrm{h}^{-1}\right)\end{array}$ & $8.3 \times 10^{-3}$ \\
\hline$\beta_{\mathrm{ij}}$ & Transfer coefficient & $0.9-1.1$ \\
\hline$K_{\mathrm{abs}}$ & $\begin{array}{l}\text { Absorption rate } \\
\text { constant }\left(\mathrm{h}^{-1}\right)\end{array}$ & 0.01 \\
\hline$d_{\mathrm{NP}}, d_{\mathrm{TB}}, d_{\mathrm{P}}$ & $\begin{array}{l}\text { Diameter of airways } \\
(\mathrm{cm})\end{array}$ & $2.8,0.5,0.1$ \\
\hline$n_{\mathrm{NP}}, n_{\mathrm{TB}}, n_{\mathrm{P}}$ & Number of airways & $1,6.6 \times 10^{4}, 6.6 \times 10^{4}$ \\
\hline$V_{\mathrm{NP}}, V_{\mathrm{TB}}, V_{\mathrm{P}}$ & $\begin{array}{l}\text { Volume of } \\
\text { compartment }\left(\mathrm{cm}^{3}\right)\end{array}$ & $92.3,94.6,1580.4$ \\
\hline \multicolumn{3}{|c|}{ Body physiological parameters ${ }^{\mathrm{b}}$} \\
\hline BW & Body weight (kg) & 70 \\
\hline$Q_{\mathrm{T}}$ & $\begin{array}{l}\text { Cardiac output } \\
\left(\mathrm{L} \mathrm{h}^{-1}\right)\end{array}$ & 286.21-330.10 \\
\hline$W_{\text {day }}$ & Daily drinking $\left(\mathrm{Lh}^{-1}\right)$ & $1.9-2.4$ \\
\hline$V_{\mathrm{L}}, V_{\mathrm{K}}, V_{\mathrm{S}}, V_{\mathrm{G}}, V_{\mathrm{Li}}$ & Volumes of tissue (L) & $0.9,0.2,11.9,1.1,1.4$ \\
\hline$Q_{\mathrm{L}}, Q_{\mathrm{K}}, Q_{\mathrm{S}}, Q_{\mathrm{G}}, Q_{\mathrm{Li}}$ & $\begin{array}{l}\text { Blood flow in tissue } \\
\left(\mathrm{Lh}^{-1}\right)\end{array}$ & $10.8,82.4,21.7,86.7,21.7$ \\
\hline
\end{tabular}

\subsection{Effect analysis}

In vivo studies-based dose-response data have been used to describe the relationships between OS and inorganic arsenic (As(III)) dose in human lung epithelial cells (BEAS-2B) [17] and human dermal keratinocyte cells (HaCaT) [18]. They used the production of lipid peroxidation (e.g. 8-isoprostane generation) and oxidative DNA damage (e.g. 8-OHdG generation) as the OS response endpoint. Their results demonstrated that As(III) evoked pronounced effect of lipid peroxidation (LPO) and DNA damage on human cells, revealing that As(III) exhibited significant dose-response behavior on OS response. A three-parameter Hill equation model was used to optimal fit the published data to reconstruct dose-response profiles taking into account the effects to human lung and skin tissues on OS response as

$E=\frac{E_{\max }}{1+(\operatorname{ED} 50 / D)^{n}}$,

where $D$ is the internal dose in the tissue, $E_{\max }$ is the maximum effect, ED50 is the dose that causes an equal effect to half of the $E_{\max }$, and $n$ is a fitting slope factor referring to as the Hill coefficient.

\subsection{Risk characterization}

Risk characterization can provide an estimate that quantifies the magnitude of individual risk. We combined the exposure analysis and the analysis of biological effects to expect the oxidative stress risk at specific target organ dose. A joint probability function or exceedence profile describes the probability of exceeding the cumulative internal dose that resulted in particular magnitude of biological effect,

$R_{D}=P(D) \times P(E \mid D)$,

where $R_{D}$ is the risk at a specific dose $D, P(D)$ is the probability of internal having tissue dose $D$, and $P(E \mid D)$ is the conditional probability of the adverse effect, given internal dose $D$ in specific target tissue.

\subsection{Uncertainty analysis}

Uncertainty is a critical component in risk assessment. Uncertainty arises from estimation of both exposure and effects. The Monte Carlo simulation was used to quantify this uncertainty and its impact on the estimation of expected risk. Ten thousand iterations of MC simulation (stability condition) were performed to obtain the $95 \%$ confidence interval (CI) for expected risk was determined on the basis of the 2.5th and 97.5th quantiles of the simulation results. A risk curve was generated from the cumulative

Table 2

Metabolic rate constants, partition coefficient, blood flow fraction and tissue density used in PBPK model.

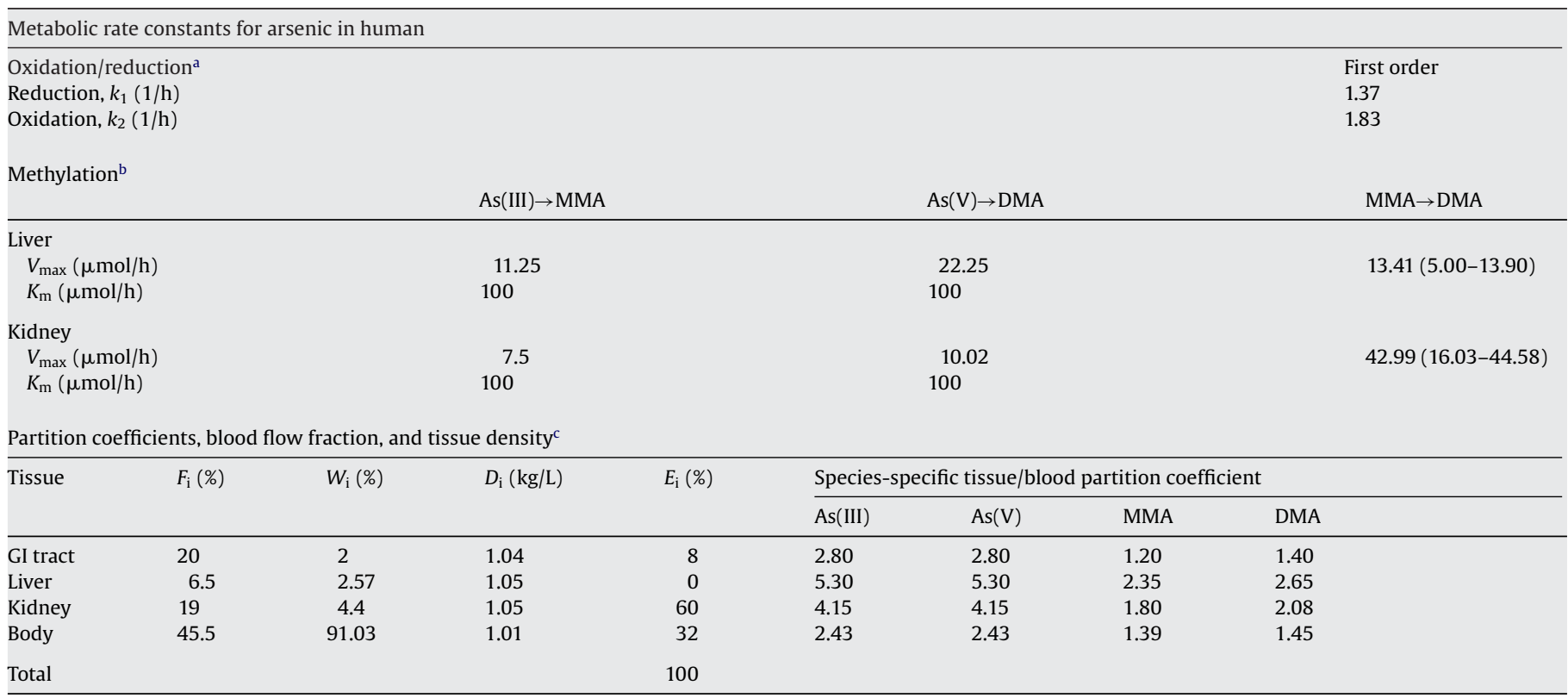

a Adopted from Yu [35].

b Adopted from Mann [32].

c Adopted from Hissink et al. [40] and Yu and Kim [41]. 
Table 3

Probability of human lung LPO and dermal DNA damage responses for semiconductor workers exceeding threshold (median with 95\% CI).

\begin{tabular}{|c|c|c|c|c|c|c|}
\hline \multirow[t]{3}{*}{ aExposure time (year) } & \multicolumn{6}{|l|}{ Exceedance risk } \\
\hline & \multicolumn{3}{|c|}{ Oxidative stress, LPO response } & \multicolumn{3}{|c|}{ Oxidative stress, oxidative DNA damage response } \\
\hline & 0.8 & 0.5 & 0.2 & 0.8 & 0.5 & 0.2 \\
\hline $0-5$ & $0.23(0.10-0.69)$ & $0.29(0.13-0.84)$ & $0.34(0.15-0.99)$ & $0.002(0.001-0.006)$ & $0.002(0.001-0.007)$ & $0.003(0.001-0.007)$ \\
\hline $5-10$ & $1.56(0.77-3.28)$ & $1.86(0.95-3.67)$ & $2.15(1.14-4.00)$ & $0.04(0.02-0.09)$ & $0.04(0.02-0.10)$ & $0.04(0.02-0.11)$ \\
\hline $10-15$ & $3.44(2.11-5.09)$ & $3.79(2.44-5.33)$ & $4.14(2.78-5.52)$ & $0.12(0.06-0.32)$ & $0.17(0.08-0.44)$ & $0.23(0.11-0.58)$ \\
\hline $15-20$ & $5.33(4.30-6.09)$ & $5.55(4.65-6.17)$ & $5.74(4.96-6.24)$ & $0.64(0.31-1.39)$ & $0.85(0.43-1.74)$ & $1.09(0.57-2.08)$ \\
\hline $20-25$ & $5.45(4.47-6.13)$ & $5.69(4.87-6.22)$ & $5.85(5.17-6.28)$ & $0.87(0.44-1.77)$ & $1.00(0.52-1.97)$ & $1.14(0.59-2.14)$ \\
\hline $25-30$ & $5.91(5.27-6.31)$ & $6.02(5.48-6.34)$ & $6.11(5.65-6.37)$ & $1.62(0.92-2.69)$ & $1.67(0.95-2.75)$ & $1.73(0.99-2.80)$ \\
\hline
\end{tabular}

a Exposure duration of $12 \mathrm{hd}-1$ for $365 \mathrm{~d}$ year- 1

distribution of simulation outcomes. The Crystal Ball software (Version 200.2, Professional Edition, Decisioneering, Inc., Denver, CO, USA) was used to perform the statistical analyses and simulations.

\section{Results}

\subsection{Exposure analysis}

Size distribution of airborne PMAs in semiconductor manufacturing facilities is best described by a lognormal model with a geometric mean diameter (GMD) of $0.29 \mu \mathrm{m}$ and a geometric standard deviation (GSD) of 0.27 (Fig. 3). Here we used five size bins $0.056-1,1-3,3-5,5-10$, and $>10 \mu \mathrm{m}$ based on the fitted particles size distribution to characterize the size distribution of airborne PMAs (Fig. 3).

Fig. 4 gives the size range-specific airborne PMAs concentrations for operator and administrator in semiconductor manufacturing facilities. Our results show that operators were exposed to higher median airborne PMAs concentrations of $20.05 \mu \mathrm{g} \mathrm{m}^{-3}$ for particle diameter $\left(d_{\mathrm{p}}\right)$ ranging from 0.056 to $1 \mu \mathrm{m}$ (Fig. $4 \mathrm{~A}$ ), whereas $2.76 \mu \mathrm{g} \mathrm{m}^{-3}$ for administrator (Fig. 4C). On the other hand, for $d_{\mathrm{p}} 1-10 \mu \mathrm{m}$, operators were subjected to median airborne PMAs concentrations ranging from 0.99 to $1.56 \mu \mathrm{g} \mathrm{m}^{-3}$ and the $0.13-0.21 \mu \mathrm{g} \mathrm{m}^{-3}$ for administrator (Fig. 4B and D). For $d_{\mathrm{p}} 1-10 \mu \mathrm{m}$, operator and administrator were exposed to 1.77 and $0.24 \mu \mathrm{g} \mathrm{m}^{-3}$ of median airborne PMAs concentrations, respectively.

Fig. 5 shows the predicted daily concentrations of particle size range-specific PMAs present in different HRT regions NP, TB and $\mathrm{P}$ for operator and administrator. The results show that the highest PMAs concentrations deposited in lung regions of semiconductor workers were estimated to be $6.79 \mu \mathrm{g} \mathrm{m}^{-3}$ (operator) and $0.94 \mu \mathrm{g} \mathrm{m}^{-3}$ (administrator) for $d_{\mathrm{p}}$ at $0.056-1 \mu \mathrm{m}$ compared to

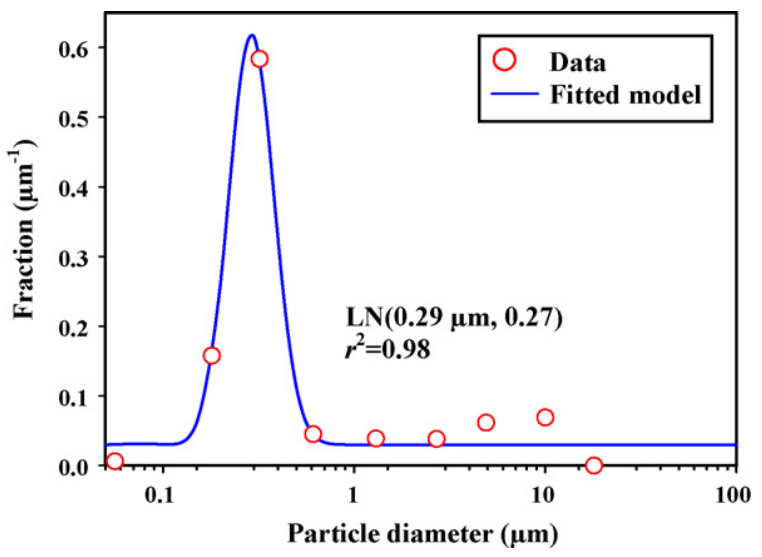

Fig. 3. Size distribution of airborne PMAs at semiconductor manufacturing facilities in $\operatorname{LN}(a, b)$ denotes the lognormal distribution with geometric mean diameters $a \mu \mathrm{m}$ and geometric standard deviation $b$.
$0.50 \mu \mathrm{g} \mathrm{m}^{-3}$ (operator) and $0.07 \mu \mathrm{g} \mathrm{m}^{-3}$ (administrator) in $d_{\mathrm{p}}$ range $1-3 \mu \mathrm{m}$ (Fig. $5 \mathrm{~A}$ and $\mathrm{B}$ ). In view of Fig. $5 \mathrm{~A}$ and $\mathrm{B}$, operator workers were subjected to relative higher PMAs concentrations for $d_{\mathrm{p}}$ at $0.056-1 \mu \mathrm{m}$ in lung regions than those of administrator, indicating that $1.72,1.74$ and $3.33 \mu \mathrm{g} \mathrm{m}^{-3}$ in lung regions NP, $\mathrm{T}$ and $\mathrm{P}$ for operator. On the other hand, PMAs for $d_{\mathrm{p}}$ at $0.056-1 \mu \mathrm{m}$ in lung region $\mathrm{P}$ yielded a higher PMAs concentrations than those of in other lung regions (Fig. 5). Operator appeared to be having higher PMAs concentrations in lung region of $\mathrm{P}\left(3.33 \mu \mathrm{g} \mathrm{m}^{-3}\right.$ for $d_{\mathrm{p}}$ at $0.056-1 \mu \mathrm{m})$ compared to that of administrator $\left(0.46 \mu \mathrm{g} \mathrm{m}^{-3}\right.$ for $d_{\mathrm{p}}$ at $\left.0.056-1 \mu \mathrm{m}\right)$.

By incorporating the internal PMAs concentrations calculated from HRT model into PBPK models, the predicted dose pattern of $\mathrm{As}(\mathrm{III})$ in the body can be estimated (Fig. 6). Peak exposure (exposure duration of $365 \mathrm{~d}$ year $^{-1}$ for 15 years) is clearly reflected by fluctuating doses in human tissue while the cumulative doses continue to increase with duration of exposure and reach steady state. The simulated tissue-specific As(III) over the times of operator can be estimated to be $13.32 \pm 1.09$ (mean \pm SD), $7.19 \pm 0.12$,
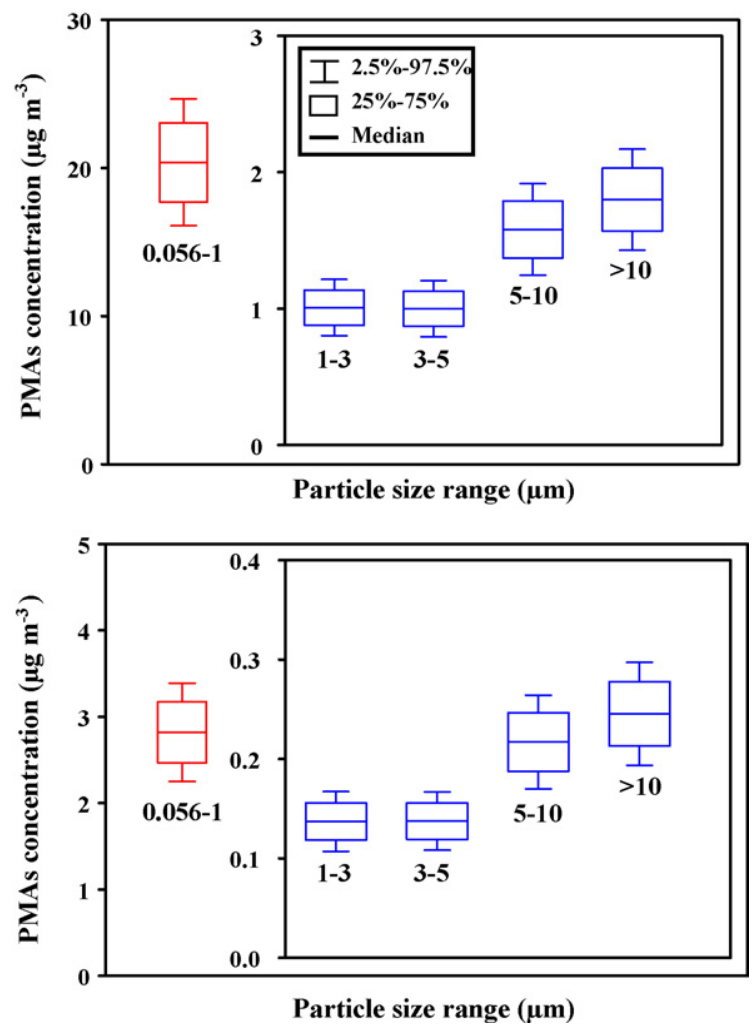

Fig. 4. Box and whisker representations of different particle size ranges of airborne PMAs concentrations in semiconductor manufacturing facilities for (A) operator and (B) administrator workers. 

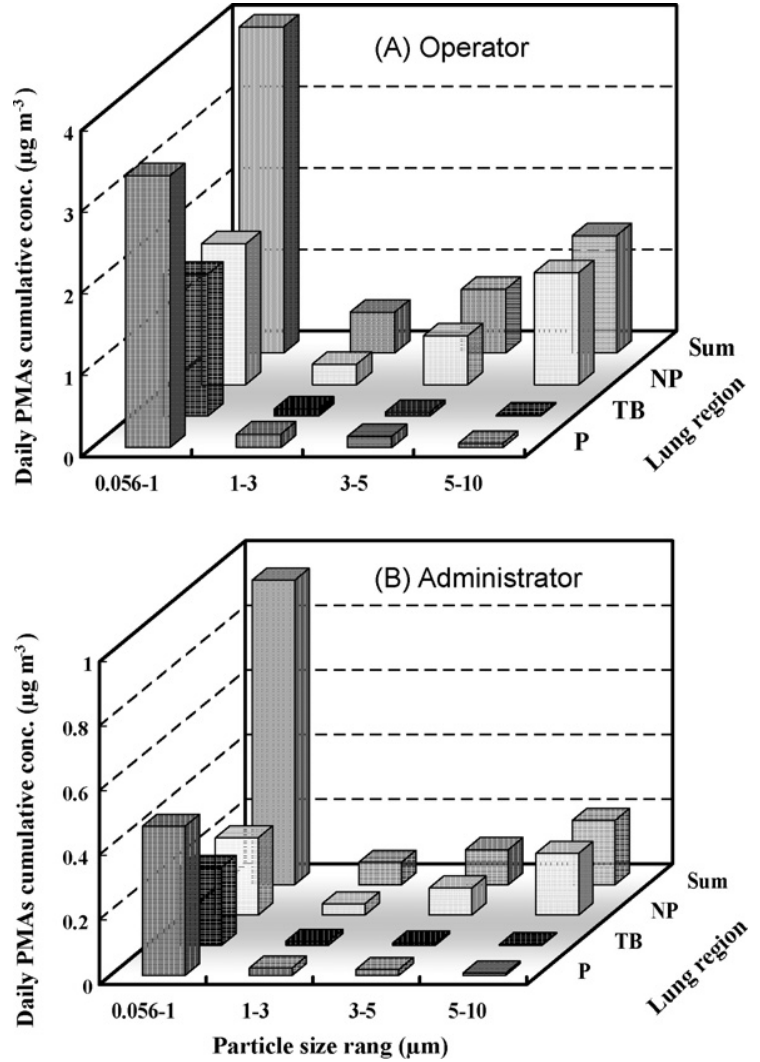

Fig. 5. Daily cumulative arsenic concentration $\left(\mu \mathrm{g} \mathrm{m}^{-3}\right)$ distributed in different lung regions at steady-state condition for (A) operator and (B) administrator.

$11.93 \pm 1.69,8.60 \pm 0.76,15.04 \pm 1.18$ and $3.12 \pm 0.27 \mu \mathrm{M}$ in lung, skin, kidney, GI tract, liver and blood, respectively (Fig. 6A).

On the other hand, for administrator, tissue-specific As(III) doses are estimated to be $2.16 \pm 0.20,1.17 \pm 0.02,2.00 \pm 0.30,1.39 \pm 0.14$, $2.43 \pm 0.22$ and $0.51 \pm 0.05 \mu \mathrm{M}$ in lung, skin, kidney, GI tract, liver and blood, respectively (Fig. 6B). The results show that the significant $\mathrm{As}(\mathrm{III})$ doses are accumulated in operator tissues, which are higher, approximately 7.3 times, than those of administrator's tissues. Moreover, the comparison of cumulative arsenic dose in human tissue implicates that the highest As(III) dose is observed in liver, followed by lung, kidney, GI tract, skin and blood. Our results show that the liver, lung and kidney may be representative organs in response to arsenic carcinogenesis.

\subsection{Effect analysis}

We reconstructed the dose-response profiles by fitting a Hill equation model and a $10,000 \mathrm{MC}$ simulation to the experimental data $[17,18]$ from As(III) dose on lung LPO $\left(r^{2}=0.99\right)$ (Fig. 7A) and dermal oxidative damage DNA $\left(r^{2}=0.99\right)$ (Fig. 7B) responses expressed by 8 -isoprostane and $8-\mathrm{OHdG}$, respectively. The median effects of As(III) dose (ED50) for LPO response were estimated to be 11.89 (95\% CI: 8.09-15.69) $\mu \mathrm{M}$, whereas ED50 estimated for oxidative DNA damage was 16.39 (95\% CI: 12.56-20.22) $\mu \mathrm{M}$. The Hill coefficient $(n)$ in LPO and oxidative DNA damage responses were estimated to be 3.12 and 3.86, respectively.

\subsection{Risk assessment}

Risk curves for the internal As(III)-induced LPO response on human lung epithelial cells indicate that the normalized human lung LPO production was estimated to be 3.79 (95\% CI: 2.44-5.33) for operator and 0.03 (95\% CI: 0.01-0.10) for administrator at a
$50 \%$ probability (risk $=0.5$ ) (Fig. $8 \mathrm{~A}$ and $\mathrm{B}$ ). On the other hand, at least $27.21 \%$ (95\% CI: $12.71-67.02 \%$ ) for operator and $0.03 \%$ (95\% CI: $0.01-0.07 \%$ ) for administrator having $10 \%$ probability subjected human dermal keratinocyte to suffer oxidative DNA damage responses (Fig. 8C and D). Our analysis thus indirectly indicates that the operator workers at semiconductor manufacturing facilities may induce a significant risk on OS response in the lung and skin tissue, whereas there is no potential risk posed to administrator. Table 3 summarizes the exposure time-specific exceeding thresholds for the probabilities of lung LPO and dermal DNA damage responses at risk $0.2,0.5$, and 0.8 for semiconductor workers of operator in semiconductor manufacturing facilities exposed to airborne PMAs (Table 3).

\section{Discussion}

\subsection{Hill-PBPK model}

To the best of our knowledge, this is the first systemic evaluation assessing in the potential occupational exposure risk for workers in semiconductor manufacturing facilities exposed to airborne PMAs. In this study we present an approach by linking model of exposure, internal dosimetry and health effects to
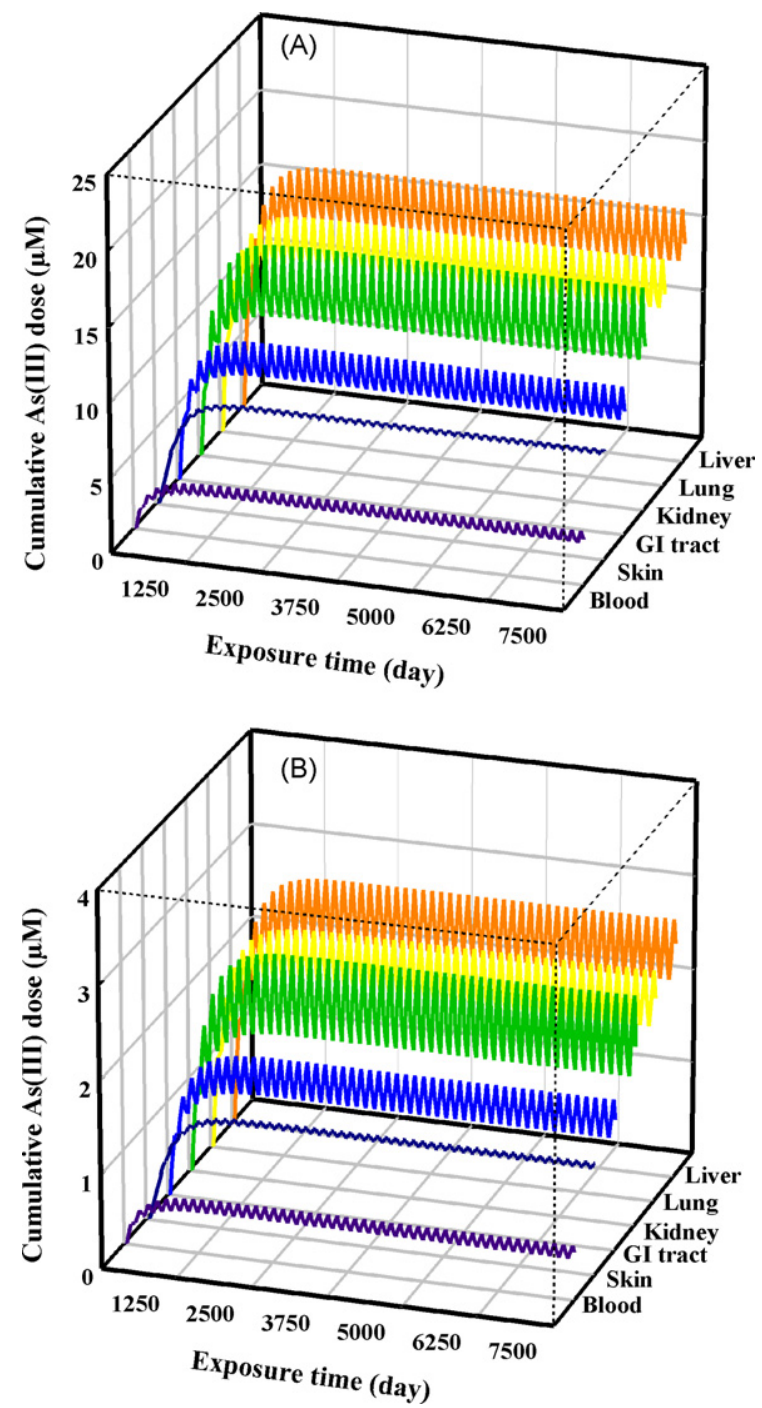

Fig. 6. Simulated time-course arsenic doses of human tissues for (A) operator and (B) administrator. 

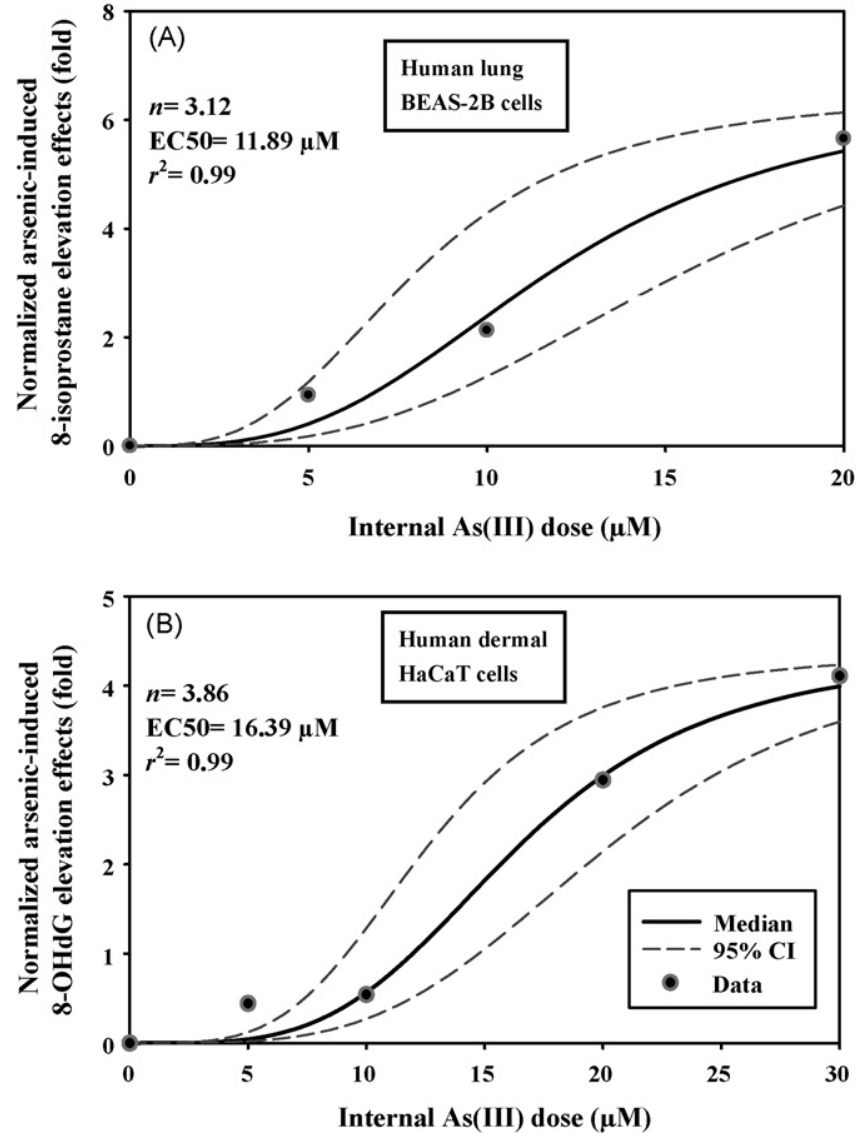

Fig. 7. Reconstructed dose-response profiles optimal fitted by a three parameters Hill equation model with 95\% confidence interval in (A) HaCaT and (B) BEAS-2B cells for PMAs cumulative dose.

estimate the risk of long-term exposure to airborne PMAs on human health. The HRT model was employed to describe the cumulative concentration of particle size range-specific PMAs deposited in different lung regions NP, TB and P, respectively. The Hill model was used to reconstruct dose-response profiles based on data of As(III) on human lung epithelial and dermal keratinocyte cells to correlate OS response. A PBPK model was applied to predict the internal dose of inorganic arsenic released by inhaled PMAs in human tissues on long-term exposure to airborne PMAs, estimating the likelihood of OS risk. Two major findings were presented: (i) the estimated half-maximum effect of As(III) dose (ED50) for LPO response on human lung epithelial cells was estimated to be 11.89 (95\% CI: 8.09-15.69) $\mu \mathrm{M}$ and ED50 estimate for oxidative DNA damage on human dermal keratinocyte cells was 16.39 (95\% CI: 12.56-20.22) $\mu \mathrm{M}$ and (ii) the long-term exposure risk curves (Fig. 8) are the pivotal results for public policy.

Sheehy and Jones [1] and Hwang et al. [4] both suggested that the workers would be exposed to higher levels of PMAs during wafer manufacturing process or cleaning and maintaining the equipment. Generally, most of operators were working in major semiconductor manufacturing operation. It was reasonable to expect that they could have experienced relative higher airborne PMAs levels when they working or disassembling and cleaning the equipments. This is consistent with our findings. Results of our study show that PMAs concentration deposited in lung regions of operator are significantly higher than that of administrator. Meanwhile, the internal arsenic dose in human tissues for operator has also a relative elevated than that of administrator. These findings indicate that the significant high arsenic dose in tissues may be associated with long-term high exposure to PMAs for operator.

\subsection{OS risk for semiconductor workers}

It has been widely demonstrated that long-term arsenic exposure may pose the induction of OS response. In panel and population studies, long-term high arsenic exposure is associated with evidence of an induction of OS response as indicated by an increase in serum LPO [21] and high level of reactive oxidants in plasma [36]. On the other hand, there are some similar reports, with increased index of LPO (Malondialdehyde) levels in the blood of arsenic-exposed optoelectronic workers [23], and a significantly elevated urinary biomarker of oxidative DNA damage (8-OHdG) in semiconductor workers exposed to arsenic [22]. Hughes [37], however, indicated that these biological monitoring studies lacked a robust risk assessment for arsenic exposure, and may need to link to target tissue dose, as well as to an adverse health effect in humans. Our proposed risk analysis may compensate this disadvantage by using a risk-based framework of linking exposure, internal dosimetry and health effects at the semiconductor manufacturing facilities where may encounter PMAs.

Taken together, our results show that administrators at the semiconductor manufacturing facilities are unlikely to pose substantial OS risk. On the other hand, the operators have significant risk on lung LPO response and skin oxidative DNA damage effect through inhalation exposure of PMAs. Our studies further indicate that the marked risk on lung LPO response can occur in operator workers who have been exposed for at least 5 years, as well as skin oxidative DNA damage effect for 10-15 years (Table 1). In view of the higher OS risk in operator groups, which may be attributed to the higher

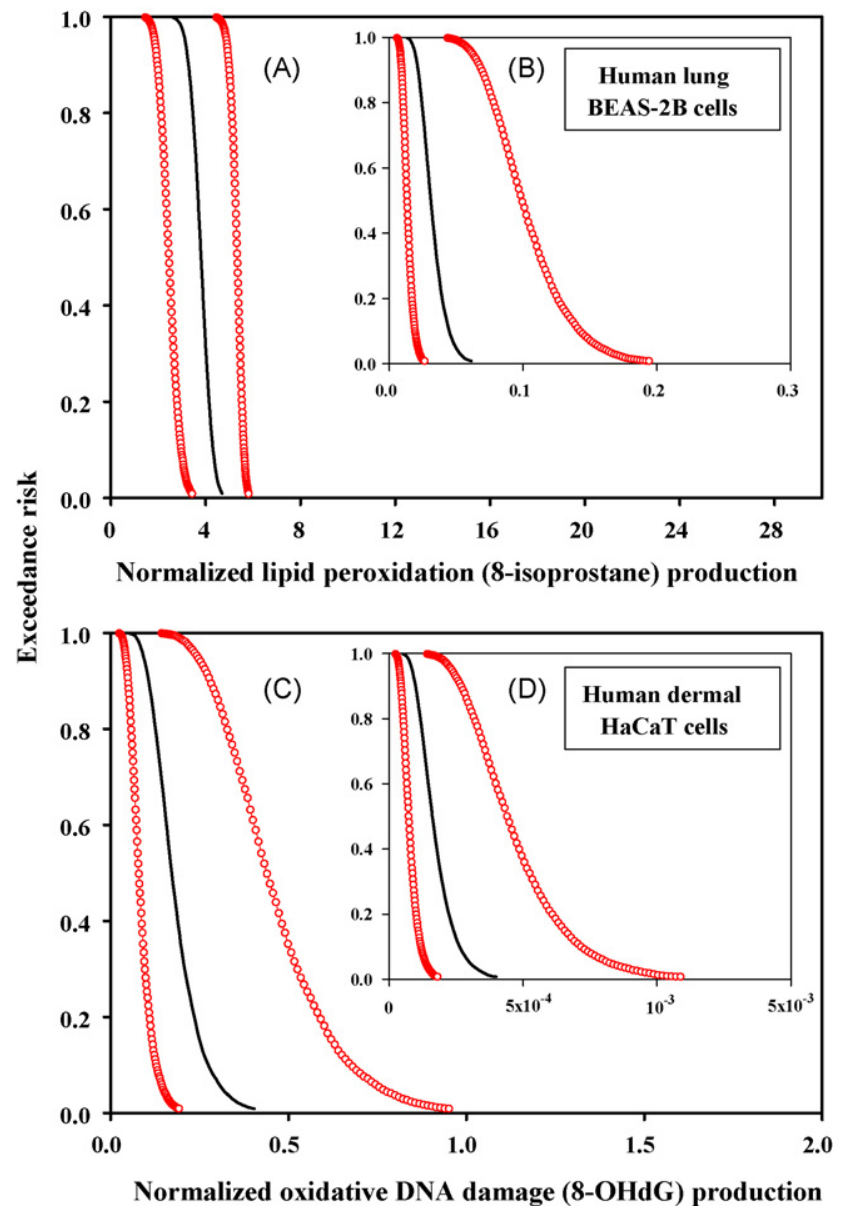

Fig. 8. Estimated exceedence risk curves with $95 \%$ confidence interval in BEAS-2B and HaCaT cells, respectively, for (A and C) operator and for (B and D) administrator exposed to PMAs for 15-year duration in semiconductor manufacturing facilities. 
exposure concentration of airborne PMAs and the accumulation effect of long-term exposure to PMAs.

\subsection{Study limitations}

Although our approach is consistent with many recent recommendations [37] and is considerable advance over qualitative risk-assessment tools, there are, however, a number of limitations for caution. First, the limitations of our data sources existed, particular the inherent problem of uncertainty and variability of the data sources. Nevertheless, our probabilistic risk-based analysis provides a broad context for the interpretation of regional airborne PMAs-related inhalation risk profiling that produced diverging and controversial outcomes, which have economic and policy implications.

Second, we provide a PBPK model that takes into account physiological and biochemical characteristics to simulate dose distributions of inorganic arsenic in human tissues, which could more accurately predict an adverse human health effect. We made explicit assumptions about PBPK modeling work in this study, as well as how the model was fairly limited. The following points may give the explanations: (1) physiological parameters, absorption and metabolism rate constants of arsenic rested on data from literature, each with its own set of assumption; (2) arsenic exposure route, in this study we strictly consider the inhalation exposure route, although dermal exposure is also an important route of arsenic exposure; (3) we assume that airborne PMAs generated from containing-arsenic by-products in semiconductor manufacturing facilities can be as the form of As(III) to absorption, distribution, metabolism and elimination by human body; and (4) we did not take into account the other PM components that causing oxidative damage in cells. Yet, combining physiologically based pharmacokinetic aspects with quality data can help us to effectively reduce variability for exposure assessment of PMAs in semiconductor manufacturing facilities.

Finally, the OS risk assessment of arsenic remains difficult, particular due to the complex biochemistry of inorganic arsenic in human tissues, as well as they could induce OS to human tis- sues cells [12,38]. Fujino et al. [39] found that the subjects with arsenic-induced dermatosis had a distinct higher urinary level of 8-OHdG, suggesting a significantly associated with arsenic species and metabolites. Although, we carried out the internal dose profiles of inorganic arsenic $\mathrm{As}(\mathrm{III})$ and $\mathrm{As}(\mathrm{V})$ and its metabolites of DMA and MMA in human tissues (the data of $\mathrm{As}(\mathrm{V})$, MMA and DMA not shown), the critical dose-response data on human adverse health effects are limited. Thus, those related issues might need more data to assess and overcome the knowledge gap in the future study.

\subsection{Implications}

Our findings have several implications. First, our results suggest that long-term accumulative effect on human health following inhalation exposure to low-level PMAs that is appropriately reflected by significantly higher OS risk. Second, our approach should have certain advantages over methods for dose response profile selection that are dependent on the use of PMAs on hazardbased genotoxicity studies to characterize particular aspects of risk analysis. The proposed PBPK modeling used to show that the primary advantage of targeted PMAs is associated with processes involved in absorption, distribution, metabolism and elimination in human tissues. Moreover, linking Hill model-based dose-response relationships and PBPK model can provide a valuable theoretical advantage over traditional models. It can potentially take account of physiological and biochemical characteristics affecting PMAsrelated adverse health response. A further inherent benefit to the Hill-PBPK approach is to provide interplay among system approach, regulator processes, and risk management.

In conclusion, our results show that operator workers have potential risk on lung and dermal exposure at relatively high airborne PMAs concentration after working over 15 years. Reduction of direct inhalation and skin contact from PMAs that decrease the frequency of inhaled and dermal exposure at workplace by wearing respirator and clean room garment could provide a certain level of protection at the semiconductor manufacturing facilities.

\section{Appendix A. Equations used in the proposed HRT and PBPK models}

\section{A.1. HRT model}

$$
\begin{aligned}
& \frac{d C_{1}(k, t)}{d t}=C_{I}(k, t) \frac{Q_{i}}{V_{1}}-C_{1}(k, t)\left[\lambda_{d_{1}}(k)+\lambda_{s_{1}}(k)+\lambda_{i m_{1}}(k)\right]-C_{1}(k, t) \varepsilon_{1}(k) \frac{Q_{i}}{V_{1}}-C_{1}(k, t) \beta_{21} \frac{Q_{i}}{V_{1}}-C_{1}(k, t) \frac{Q_{i}}{V_{1}}+C_{2}(k, t) \beta_{12} \frac{Q_{i}}{V_{1}} \\
& \frac{d C_{2}(k, t)}{d t}=C_{1}(k, t) \beta_{21} \frac{Q_{i}}{V_{2}}-C_{2}(k, t)\left[\lambda_{d_{2}}(k)+\lambda_{s_{2}}(k)+\lambda_{i m_{2}}(k)\right]-C_{2}(k, t) \varepsilon_{2}(k) \frac{Q_{i}}{V_{2}}-C_{2}(k, t) \beta_{32} \frac{Q_{i}}{V_{2}}-C_{2}(k, t) \beta_{12} \frac{Q_{i}}{V_{1}}+C_{3}(k, t) \beta_{23} \frac{Q_{i}}{V_{3}} \\
& \frac{d C_{3}(k, t)}{d t}=C_{3}(k, t) \beta_{32} \frac{Q_{i}}{V_{3}}-C_{3}(k, t)\left[\lambda_{d_{3}}(k)+\lambda_{s_{3}}(k)+\lambda_{i m_{3}}(k)\right]-C_{3}(k, t) \varepsilon_{3}(k) \frac{Q_{i}}{V_{3}}-C_{3}(k, t) \beta_{23} \frac{Q_{i}}{V_{3}}-C_{3}(k, t) C_{L}(t) \\
& \frac{d C_{4}}{d t}=V_{\text {Lung }} \frac{d C_{\text {Lung }}}{d t}=K_{\text {uptake }}
\end{aligned}
$$

A.2. PBPK model

$$
\begin{aligned}
& \text { A.2.1. Lung } \\
& \text { As(III) } \frac{d A_{\text {Lung }}^{3+}}{d t}=Q_{\text {Lung }} \times\left(C_{a}^{3+}-\frac{C_{\text {Lung }}^{3+}}{P_{\text {Lung }}^{3+}}\right)+\left(k_{1} \times C_{\text {Lung }}^{5+}-k_{2} \times C_{\text {Lung }}^{3+}\right) \times V_{\text {Lung }}+K_{\text {uptake }}^{3+} \\
& \operatorname{As}(\mathrm{V}) \frac{d A_{\text {Lung }}^{5+}}{d t}=Q_{\text {Lung }} \times\left(C_{a}^{5+}-\frac{C_{\text {Lung }}^{5+}}{P_{\text {Lung }}^{5+}}\right)-\left(k_{1} \times C_{\text {Lung }}^{5+}-k_{2} \times C_{\text {Lung }}^{5+}\right) \times V_{\text {Lung }}
\end{aligned}
$$


MMA $\frac{d A_{\text {Lung }}^{\mathrm{MMA}}}{d t}=Q_{\text {Lung }} \times\left(C_{a}^{\mathrm{MMA}}-\frac{C_{\text {Lung }}^{\mathrm{MMA}}}{P_{\text {Lung }}^{\mathrm{MMA}}}\right)$

DMA $\frac{d A_{\text {Lung }}^{\text {DMA }}}{d t}=Q_{\text {Lung }} \times\left(C_{a}^{\text {DMA }}-\frac{C_{\text {Lung }}^{\text {DMA }}}{P_{\text {Lung }}^{\text {DMA }}}\right)$

A.2.2. Kidney (urine)

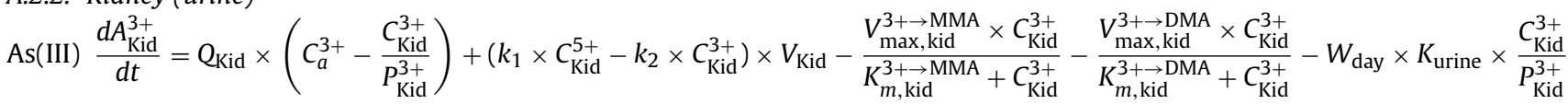

$\operatorname{As}(\mathrm{V}) \frac{d A_{\mathrm{Kid}}^{5+}}{d t}=Q_{\text {Kid }} \times\left(C_{a}^{5+}-\frac{C_{\text {Kid }}^{5+}}{P_{\text {Kid }}^{5+}}\right)-\left(k_{1} \times C_{\text {Kid }}^{5+}-k_{2} \times C_{\text {Kid }}^{3+}\right) \times V_{\text {Kid }}-W_{\text {day }} \times K_{\text {urine }} \times \frac{C_{\text {Kid }}^{5+}}{P_{\text {Kid }}^{5+}}$

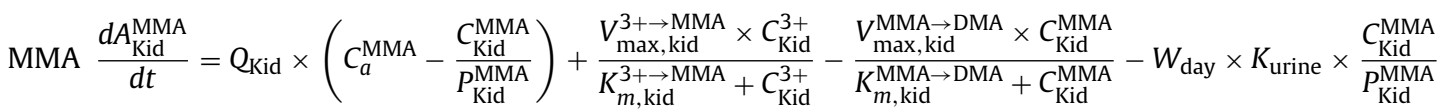

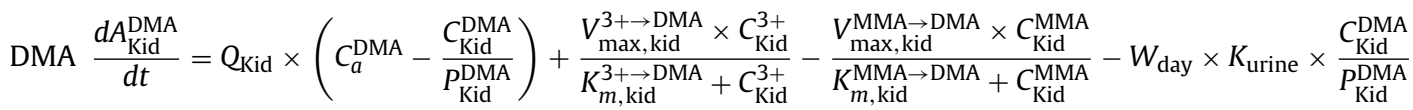

A.2.3. Skin

$\operatorname{As}(\mathrm{III}) \frac{d A_{\text {Skin }}^{3+}}{d t}=Q_{\text {Skin }} \times\left(C_{a}^{3+}-\frac{C_{\text {Skin }}^{3+}}{P_{\text {Skin }}^{3+}}\right)+\left(k_{1} \times C_{\text {Skin }}^{5+}-k_{2} \times C_{\text {Skin }}^{3+}\right) \times V_{\text {Skin }}-W_{\text {day }}+K_{\text {Skin }} \times C_{\text {Skin }}^{3+}$

$\operatorname{As}(\mathrm{V}) \frac{d A_{\text {Skin }}^{5+}}{d t}=Q_{\text {Skin }} \times\left(C_{a}^{5+}-\frac{C_{\text {Skin }}^{5+}}{P_{\text {Skin }}^{5+}}\right)-\left(k_{1} \times C_{\text {Skin }}^{5+}-k_{2} \times C_{\text {Skin }}^{5+}\right) \times V_{\text {Skin }}-W_{\text {day }}+K_{\text {Skin }}+C_{\text {Skin }}^{5+}$

MMA $\frac{d A_{\text {Skin }}^{\mathrm{MMA}}}{d t}=Q_{\text {Skin }} \times\left(C_{a}^{\mathrm{MMA}}-\frac{C_{\text {Skin }}^{\mathrm{MMA}}}{P_{\text {Skin }}^{\mathrm{MMA}}}\right)$

DMA $\frac{d A_{\text {Skin }}^{\mathrm{DMA}}}{d t}=Q_{\text {Skin }} \times\left(C_{a}^{\mathrm{DMA}}-\frac{C_{\text {Skin }}^{\mathrm{DMA}}}{P_{\text {Skin }}^{\mathrm{DMA}}}\right)$

A.2.4. G. I. tract

$\mathrm{As}(\mathrm{III}) \frac{d A_{\mathrm{GI}}^{3+}}{d t}=Q_{\mathrm{GI}} \times\left(C_{a}^{3+}-\frac{C_{\mathrm{GI}}^{3+}}{P_{\mathrm{GI}}^{3+}}\right)-Q_{\mathrm{GI}} \times\left(\frac{C_{\mathrm{GI}}^{3+}}{P_{\mathrm{GI}}^{3+}}-\frac{C_{\mathrm{Liver}}^{3+}}{P_{\mathrm{Liver}}^{3+}}\right)+\left(k_{1} \times C_{\mathrm{GI}}^{5+}-k_{2} \times C_{\mathrm{GI}}^{3+}\right) \times V_{\mathrm{GI}}-W_{\mathrm{day}} \times K_{\mathrm{GI}} \times C_{\mathrm{GI}}^{3+}$

$\mathrm{As}(\mathrm{V}) \frac{d A_{\mathrm{GI}}^{5+}}{d t}=Q_{\mathrm{GI}} \times\left(C_{a}^{5+}-\frac{C_{\mathrm{GI}}^{5+}}{P_{\mathrm{GI}}^{5+}}\right)-Q_{\mathrm{GI}} \times\left(\frac{C_{\mathrm{GI}}^{5+}}{P_{\mathrm{GI}}^{5+}}-\frac{C_{\mathrm{Liver}}^{5+}}{P_{\mathrm{Liver}}^{5+}}\right)-\left(k_{1} \times C_{\mathrm{GI}}^{5+}-k_{2} \times C_{\mathrm{GI}}^{3+}\right) \times V_{\mathrm{GI}}-W_{\mathrm{day}} \times K_{\mathrm{GI}} \times C_{\mathrm{GI}}^{5+}$

MMA $\frac{d A_{\mathrm{GI}}^{\mathrm{MMA}}}{d t}=Q_{\mathrm{GI}} \times\left(C_{a}^{\mathrm{MMA}}-\frac{C_{\mathrm{GI}}^{\mathrm{MMA}}}{P_{\mathrm{GI}}^{\mathrm{MMA}}}\right)-Q_{\mathrm{GI}} \times\left(\frac{C_{\mathrm{GI}}^{\mathrm{MMA}}}{P_{\mathrm{GI}}^{\mathrm{MMA}}}-\frac{C_{\mathrm{Liver}}^{\mathrm{MMA}}}{P_{\mathrm{Liver}}^{\mathrm{MMA}}}\right)-W_{\text {day }} \times K_{\mathrm{GI}} \times C_{\mathrm{GI}}^{\mathrm{MMA}}$

DMA $\frac{d A_{\mathrm{GI}}^{\mathrm{DMA}}}{d t}=Q_{\mathrm{GI}} \times\left(C_{a}^{\mathrm{DMA}}-\frac{C_{\mathrm{GI}}^{\mathrm{DMA}}}{P_{\mathrm{GI}}^{\mathrm{DMA}}}\right)-Q_{\mathrm{GI}} \times\left(\frac{C_{\mathrm{GI}}^{\mathrm{DMA}}}{P_{\mathrm{GI}}^{\mathrm{DMA}}}-\frac{C_{\mathrm{Liver}}^{\mathrm{DMA}}}{P_{\text {Liver }}^{\mathrm{DMA}}}\right)-W_{\text {day }} \times K_{\mathrm{GI}} \times C_{\mathrm{GI}}^{\mathrm{DMA}}$

A.2.5. Liver

$\operatorname{As}($ III $)$

$\frac{d A_{\text {Liver }}^{3+}}{d t}=Q_{\text {Liver }} \times\left(C_{a}^{3+}-\frac{C_{\text {Liver }}^{3+}}{P_{\text {Liver }}^{3+}}\right)+Q_{\mathrm{GI}} \times\left(\frac{C_{\mathrm{GI}}^{3+}}{P_{\mathrm{GI}}^{3+}}-\frac{C_{\text {Liver }}^{3+}}{P_{\text {Liver }}^{3+}}\right)-\left(k_{1} \times C_{\text {Liver }}^{5+}-k_{2} \times C_{\text {Liver }}^{3+}\right)$

$\times V_{\text {Liver }}-W_{\text {Biliary }} \times C_{\text {Liver }}^{3+}-\frac{V_{\text {max, Liver }}^{3+\rightarrow \text { MMA }} \times C_{\text {Liver }}^{3+}}{K_{m, \text { Liver }}^{3+\rightarrow \text { MMA }}+C_{\text {Liver }}^{3+}}-\frac{V_{\text {max,Liver }}^{3+\rightarrow \text { DMA }} \times C_{\text {Liver }}^{3+}}{K_{m, \text { Liver }}^{3+\rightarrow \text { DMA }}+C_{\text {Liver }}^{3+}}$

$\operatorname{As}(\mathrm{V}) \frac{d A_{\text {Liver }}^{5+}}{d t}=Q_{\text {Liver }} \times\left(C_{a}^{5+}-\frac{C_{\text {Liver }}^{5+}}{P_{\text {Liver }}^{5+}}\right)+Q_{\mathrm{GI}} \times\left(\frac{C_{\mathrm{GI}}^{5+}}{P_{\mathrm{GI}}^{5+}}-\frac{C_{\mathrm{Liver}}^{5+}}{P_{\text {Liver }}^{5+}}\right)-\left(k_{1} \times C_{\mathrm{Liver}}^{5+}-k_{2} \times C_{\mathrm{Liver}}^{3+}\right)$

$\times V_{\text {Liver }}-W_{\text {Biliary }} \times C_{\text {Liver }}^{5+}$

MMA

$\frac{d A_{\mathrm{Liver}}^{\mathrm{MMA}}}{d t}=Q_{\mathrm{Liver}} \times\left(C_{a}^{\mathrm{MMA}}-\frac{C_{\mathrm{Liver}}^{\mathrm{MMA}}}{P_{\mathrm{Liver}}^{\mathrm{MMA}}}\right)+Q_{\mathrm{GI}} \times\left(\frac{C_{\mathrm{GI}}^{\mathrm{MMA}}}{P_{\mathrm{GI}}^{\mathrm{MMA}}}-\frac{C_{\mathrm{Liver}}^{\mathrm{MMA}}}{P_{\mathrm{Liver}}^{\mathrm{MMA}}}\right)+\frac{V_{\text {max, Liver }}^{3+\rightarrow \mathrm{MMA}} \times C_{\mathrm{Liver}}^{3+}}{K_{m, \mathrm{Liver}}^{3+\rightarrow \mathrm{MMA}}+C_{\mathrm{Liver}}^{3+}}$ $-\frac{V_{\text {max, Liver }}^{\mathrm{MMA} \rightarrow \mathrm{DMA}} \times C_{\text {Liver }}^{\mathrm{MMA}}}{K_{m, \text { Liver }}^{\mathrm{MMMA}}+C_{\text {Liver }}^{\mathrm{MMA}}}-W_{\text {Biliary }} \times C_{\text {Liver }}^{\mathrm{MMA}}$ 


$$
\begin{aligned}
& \frac{d A_{\text {Liver }}^{\text {DMA }}}{d t}=Q_{\text {Liver }} \times\left(C_{a}^{\text {DMA }}-\frac{C_{\text {Liver }}^{\text {DMA }}}{P_{\text {Liver }}^{\text {DMA }}}\right)+Q_{\mathrm{GI}} \\
& \times\left(\frac{C_{\text {GI }}^{\text {DMA }}}{P_{\mathrm{Gl}}^{\text {DMA }}}-\frac{C_{\text {Liver }}^{\text {DMA }}}{P_{\text {Liver }}^{\text {DMA }}}\right)+\frac{V_{\text {max,Liver }}^{3+\rightarrow \text { DMA }} \times C_{\text {Liver }}^{3+}}{K_{m, \text { Liver }}^{3+\rightarrow \text { DMA }}+C_{\text {Liver }}^{3+}} \\
&+\frac{V_{\text {max,Liver }}^{\text {MMA }} \times C_{\text {Liver }}^{\text {MMA }}}{K_{m, \text { Liver }}^{\text {MMA } \rightarrow \text { DMA }}+C_{\text {Liver }}^{\text {MMA }}}-W_{\text {Biliary }} \times C_{\text {Liver }}^{\text {DMA }}
\end{aligned}
$$$$
\text { DMA }
$$

\section{A.2.6. Blood}

$$
\begin{aligned}
\operatorname{As}(\mathrm{III}) \frac{d A_{a}^{3+}}{d t}= & \left(\sum_{i=1}^{6} Q_{i} \times \frac{C_{i}^{3+}}{P_{i}^{3+}}-\sum_{i=1}^{6} Q_{i} \times C_{a}^{3+}\right) \\
& +\left(K_{1} \times C_{a}^{5+}-K_{2} \times C_{a}^{3+}\right) \times V_{a}
\end{aligned}
$$

$$
\begin{aligned}
\operatorname{As}(\mathrm{V}) \frac{d A_{a}^{5+}}{d t}= & \left(\sum_{i=1}^{6} Q_{i} \times \frac{C_{i}^{5+}}{P_{i}^{5+}}-\sum_{i=1}^{6} Q_{i} \times C_{a}^{5+}\right) \\
& -\left(K_{1} \times C_{a}^{5+}-K_{2} \times C_{a}^{3+}\right) \times V_{a}
\end{aligned}
$$

$$
\text { MMA } \frac{d A_{a}^{\mathrm{MMA}}}{d t}=\left(\sum_{i=1}^{6} Q_{i} \times \frac{C_{i}^{\mathrm{MMA}}}{P_{i}^{\mathrm{MMA}}}-\sum_{i=1}^{6} Q_{i} \times C_{a}^{\mathrm{MMA}}\right)
$$

$\frac{d A_{a}^{\mathrm{DMA}}}{d t}=\left(\sum_{i=1}^{6} Q_{i} \times \frac{C_{i}^{\mathrm{DMA}}}{P_{i}^{\mathrm{DMA}}}-\sum_{i=1}^{6} Q_{i} \times C_{a}^{\mathrm{DMA}}\right)$

\section{References}

[1] J.W. Sheehy, J.H. Jones, Assessment of arsenic exposures and controls in gallium arsenide production, Am. Ind. Hyg. Assoc. 54 (1993) 61-69.

[2] M.E. Williams, D.G. Baldwin, Semiconductor Industrial Hygiene Handbook, Noyes, Park Ridge, NJ, 1994.

[3] Y.H. Hwang, S.C. Chen, Monitoring of low level arsenic exposure during maintenance of ion implanters, Arch. Environ. Health 55 (2000) 347354.

[4] Y.H. Hwang, Z.Y. Lee, J.D. Wang, Y.M. Hsueh, I.C. Lu, W.L. Yao, Monitoring of arsenic exposure with speciated urinary inorganic arsenic metabolites for ion implanter maintenance engineers, Environ. Res. 90 (2002) (2002) 207216.

[5] H.W. Chen, Exposure and health risk of gallium, indium, and arsenic from semiconductor manufacturing industry workers, B. Environ. Contam. Toxicol. 78 (2007) 5-9.

[6] C.J. Chen, H.Y. Chiou, W.I. Huang, S.Y. Chen, Y.M. Hsueh, C.H. Tseng, L.J. Lin, M.P. Shyu, M.S. Lai, Systemic noncarcinogenic effects and developmental toxicity of inorganic arsenic, in: C.O. Abernathy, R.L. Calderon, W.R. Chappell (Eds.), Arsenic: Exposure and Health Effects, Chapman \& Hall, London, 1997, pp. 124-134.

[7] H.Y. Chiou, Y.M. Hsueh, K.F. Liaw, S.F. Hong, M.H. Chiang, Y.S. Pu, J.S. Lin, C.H. Huang, C.J. Chen, Incidence of internal cancers and ingested inorganic arsenic: a seven-year follow-up study in Taiwan, Cancer Res. 55 (1995) 12961300.

[8] J.M. Chiou, S.L. Wang, C.J. Chen, C.R. Deng, W. Lin, T.Y. Tai, Arsenic ingestion and increased microvascular disease risk: observations from the southwestern arseniasisendemic area in Taiwan, Int. J. Epidemiol. 34 (2005) 936943.

[9] A.H. Smith, G. Marshall, Y. Yuan, C. Ferreccio, J. Liaw, O. Ehrenstein, C. Steinmaus, M.N. Bates, S. Selvin, Increased mortality from lung cancer and bronchiectasis in young adults after exposure to arsenic in utero and in early childhood, Environ. Health Perspect. 14 (2006) 1293-1296.

[10] H. Yamamuchi, K. Takahashi, Y. Yamamura, Metabolism and excretion of orally and intraperitoneally administered gallium arsenide in the hamsters, Toxicology 40 (1986) 237-246.

[11] E.A. Conner, H. Yamamuchi, B.A. Fowler, Alterations in the heme biosynthetic pathway from the III-V semiconductor metal, indium arsenide (InAs), Chem. Biol. Interact. 96 (1995) 273-285.

[12] K.T. Kitchin, Recent advances in arsenic carcinogenesis: modes of action, animal model systems, and methylated arsenic metabolites, Toxicol. Appl. Pharm. 172 (2001) 249-261.
[13] A. Basu, J. Mahata, S. Gupta, A.K. Girl, Genetic toxicology of a paradoxical human carcinogen, arsenic: a review, Mutat. Res. 488 (2001) 171-194.

[14] R.C. Lantz, A.M. Hays, Role of oxidative stress in arsenic-induced toxicity, Drug Metab. Rev. 38 (2006) 791-804.

[15] H. Esterbauer, P. Eckl, A. Ortner, Possible mutagens derived from lipid and lipid precursors, Mutat. Res. 238 (1990) 223-233.

[16] L.J. Marnett, Oxyradicals and DNA damage, Carcinogenesis 21 (2000) 361370.

[17] S.G. Han, V. Castranova, V. Vallyathan, Heat shock protein 70 as an indicator of early lung injury caused by exposure to arsenic, Mol. Cell. Biochem. 277 (2005) 153-164.

[18] W. Ding, L.G. Hudson, K.J. Liu, Inorganic arsenic compounds cause oxidative damage to DNA and protein by inducing ROS and RNS generation in human keratinocytes, Mol. Cell. Biochem. 279 (2005) 105-112.

[19] O. Ramos, L. Carrizales, L. Yáñez, J. Mejía, L. Batres, D. Ortíz, B.F. Díaz, Arsenic increased lipid peroxidation in rat tissues by a mechanism independent of glutathione levels, Environ. Health Perspect. 103 (Suppl. 1) (1995) 8588.

[20] S.J.S. Flora, Arsenic-induced oxidative stress and its reversibility following combined administration of $\mathrm{N}$-acetylcysteine and meso 2,3-dimercaptosuccinic acid in rats, Clin. Exp. Pharmacol. 26 (1999) 865-869.

[21] J. Pi, H. Yamauchi, Y. Kumangai, G. Sun, T. Yoshida, H. Aikawa, C.H. Rich, N. Shimojo, Evidence for induction of oxidative stress caused by chronic exposure of Chinese residents to arsenic contained in drinking water, Environ. Health Perspect. 110 (2002) 331-336.

[22] C.W. Hu, C.H. Pan, Y.L. Huang, M.T. Wu, L.W. Cheng, C.J. Wang, M.R. Chao, Effects of arsenic exposure among semiconductor workers: a cautionary note on urinary 8-oxo-7,8-dihydro-2'-deoxyguanosine, Free Radic. Biol. Med. 40 (2006) 1273-1278.

[23] Y.H. Liao, L.C. Hwang, J.S. Kao, S.J. Yiin, S.F. Lin, C.H. Lin, Y.C. Lin, C.T. Aw, Lipid peroxidation in workers exposed to aluminium, gallium, indium, arsenic, and antimony in the optoelectronic industry, J. Occup. Environ. Med. 46 (2006) 931-936.

[24] L. Liu, J.R. Trimarchi, P. Navarro, M.A. Blasco, D.L. Keefe, Oxidative stress contributes to arsenic-induced telomere attrition, chromosome instability, and apoptosis, J. Biol. Chem. 278 (2003) 31998-32004.

[25] C.D. Kamat, D.E. Green, S. Curilla, L. Warnke, J.W. Hamilton, S. Sturup, C. Clark M.A. Ihnat, Role of HIF signaling on tumorigenesis in response to chronic lowdose arsenic administration, Toxicol. Sci. 86 (2005) 248-257.

[26] D. Baldwin, B. King, L. Scarpace, Ion implanters: chemical and radiation safety, Solid State Technol. 31 (1998) 99-105.

[27] F.F. Álvarez, M.T. Rodríguez, A.J. Fernández, A.G. Dabán, Physical speciation of arsenic, mercury, lead, cadmium and nickel in inhalable atmospheric particles, Anal. Chim. Acta 524 (2004) 33-40.

[28] J.D. Herner, P.G. Green, M.J. Kleeman, Measuring the trace elemental composition of size-resolved airborne particles, Environ. Sci. Technol. 40 (2006) 1925-1933.

[29] ICRP, Human Respiratory Tract Model for Radiological Protection a Report of a Task Group of the International Commission on Radiological Protection, ICRP Publication, New York, Elsevier, 1994.

[30] C.M. Liao, S.C. Chen, A probabilistic modeling approach to assess human inhalation exposure risk to airborne aflatoxin $B_{1}\left(A_{F B}\right)$, Atmos. Environ. 39 (2005) 6481-6490.

[31] C.P. Chio, S.C. Chen, K.C. Chiang, W.C. Chou, C.M. Liao, Oxidative stress risk analysis for exposure to diesel exhaust particle-induced reactive oxygen species, Sci. Total Environ. 387 (2007) 113-127.

[32] S. Mann, P.O. Droz, M. Vahter, A physiological based pharmacokinetic mode for arsenic exposure. II. Validation and application in humans, Toxicol. Appl. Pharm. 140 (1996) 471-486.

[33] D. Yu, A physiologically based pharmacokinetic model of inorganic arsenic: a short-term oral exposure model for humans, Chemosphere 39 (1999) 2737-2747.

[34] C.M. Liao, T.L. Lin, S.C. Chen, A Weibull-PBPK model for assessing risk of arsenicrelated children skin lesions, Sci. Total Environ. 392 (2008) 203-217.

[35] D. Yu, A physiologically based pharmacokinetic model of inorganic arsenic, Regul. Toxicol. Pharm. 29 (1999) 128-141.

[36] M.M. Wu, H.Y. Chiou, T.W. Wang, Y.M. Hsueh, I.H. Wang, C.J. Chen, T.C. Lee, Association of blood arsenic levels with increased reactive oxidants and decreased antioxidant capacity in a human population of northeastern Taiwan, Environ. Health Perspect. 109 (2001) 1011-1017.

[37] M.F. Hughes, Biomarkers of exposure: a case study with inorganic arsenic, Environ. Health Perspect. 114 (2006) 1790-1796.

[38] T. Schwerdtle, I. Walter, I. Mackiw, A. Hartwig, Induction of oxidative DNA damage by arsenite and its trivalent and pentavalent methylated metabolites in cultured human cells and isolated DNA, Carcinogenesis 24 (2003) 967974.

[39] Y. Fujino, X.J. Guo, J. Liu, I.P. Matthews, K. Shirane, K.G. Wu, H. Kasai, M. Miyatake, K. Tanabe, T. Kusuda, T. Yoshimura, Chronic arsenic exposure and urinary 8-Hydroxy-2'-deoxyguanosine in an arsenic-affected area in Inner Mongolia, China, J. Expo. Anal. Environ. Epidemiol. 15 (2005) 147-152.

[40] A.M. Hissink, L.W. Wormhoudt, P.J. Sherratt, J.D. Hayes, J.N.M. Commandeur, N.P.E. Vermeulen, P.J.V. Bladeren, A physiologically-based pharmacokinetic (PBPK) model for ethylene dibromide: relevance of extrahepatic metabolism, Food Chem. Toxicol. 38 (2000) 707-716.

[41] D. Yu, J.A. Kim, A physiologically based assessment of human exposure to radon released from groundwater, Chemosphere 54 (2004) 639-645. 